\title{
Distribution and size biomass structure of nanophytoplankton in the Strait of Gibraltar
}

\author{
Andreas Reul ${ }^{1}$, Jaime Rodríguez ${ }^{1}$, Francisco Guerrero ${ }^{2}$, Nicolás González ${ }^{3}$, \\ Juan M. Vargas ${ }^{4}$, Fidel Echevarría ${ }^{5}$, Valeriano Rodríguez ${ }^{1}$, \\ Francisco Jiménez-Gómez ${ }^{2, *}$
}

\footnotetext{
${ }^{1}$ Departamento de Ecología y Geología, and ${ }^{4}$ Departamento de Física Aplicada II, Universidad de Málaga, 29071 Málaga, Spain ${ }^{2}$ Departamento de Biología Animal, Biología Vegetal y Ecología, Universidad de Jaén, 23071 Jaén, Spain

${ }^{3}$ Instituto Español de Oceanografía, Muelle de Animas s/n, 15001 A Coruña, Spain

${ }^{5}$ Departamento de Biología, Universidad de Cádiz, 11510 Puerto Real, Cádiz, Spain
}

\begin{abstract}
The spatial distribution and size structure of microbial nanophytoplankton were analysed using flow cytometry and then related to water column structure and nutrient concentration in the Strait of Gibraltar. Microbial biomass increased as the Atlantic-Mediterranean interface (AMI) shoaled and mixing processes increased from SW to NE in the strait region. Prokaryotic phytoplankton (Prochlorococcus sp. and Synechococcus sp.) were more abundant on the Atlantic side of the strait. They showed, however, a contrasting distribution along a gradient from open, oligotrophic waters (Prochlorococcus sp. dominance) to shelf, nutrient-rich waters (Synechococcus sp. dominance). In contrast to prokaryotic picophytoplankton, eukaryotic nanophytoplankton showed the highest abundance on the Mediterranean side of the strait, affected by upwelling processes. The slope of the phytoplankton size-abundance spectra (P-SAS) smoothed as the AMI shoaled, due not only to increasing nanophytoplankton abundance but also to decreasing picophytoplankton (mainly Prochlorococcus sp.) abundance. The spatial distribution pattern and size structure of microbial phytoplankton indicate a transition from 'microbial food web' to 'grazing food web' dominating conditions from the SW to the NE of the Strait of Gibraltar.
\end{abstract}

KEY WORDS: Prokaryotic phytoplankton - Size spectra - Spatial distribution · AtlanticMediterranean interface $\cdot$ Flow cytometry

\section{INTRODUCTION}

The Strait of Gibraltar is the unique connection between the Mediterranean Sea and the Atlantic Ocean, formed by an intricate sequence of canyons, narrow sites and sills. It has historically been the focus of a large research effort (García-Lafuente et al. 2000). The Strait of Gibraltar contributes to the large-scale properties of the Mediterranean Sea, and to the thermohaline circulation of the global ocean.

The Strait of Gibraltar is the site of a baroclinic exchange between 2 basins of different densities, with the resulting density flows corresponding to the inflowing surface water from the Atlantic and the saltier westward-flowing Mediterranean water beneath. The boundary between the 2 water masses, called the Atlantic-Mediterranean interface (AMI), is identified between the isohalines of 37 and 37.5, which comprise the centre of the pycnocline. This simple 2-layer model is strongly time-dependent and affected by the interaction of the tide with bathymetry, which promotes a high variability of the interface depth with important mixing processes along the strait.

In comparison to the physical data set, ecological studies on the nutrient and plankton distribution and transport in the Strait of Gibraltar have been until recently very scarce. However, this gap of ecological data is now being filled owing to interdisciplinary and 
international research programmes focused on this area (European Union Canary Islands and Azores Gibraltar Observations [EU-CANIGO] project). The present study focuses on the microbial phytoplankton distribution during 2 summer surveys carried out in the area of the Strait of Gibraltar. The conceptual approach is based on the evidence that the food-web pathways and the fate of planktonic biomass depend on the size structure (Platt \& Denman 1977) which, in turn, is closely associated with the physical conditions, such as the direct influence of mesoscale vertical water velocities on the phytoplankton size structure through the increase of retention time of large cells within the euphotic zone (Rodríguez et al. 2001) or the size dependence for nutrient uptake (Malone 1980).

The objective of the present study was to analyse the spatial distribution of Prochlorococcus sp., Synechococcus sp., eukaryotic picophytoplankton and nanophytoplankton, as well as the corresponding microbial size abundance spectra in relation to the different hydrological structures coexisting in the region.

\section{MATERIALS AND METHODS}

Fieldwork. Three transects (eastern, central and western) were sampled on 8 consecutive days in June (18 to 25) and September (2 to 9) 1997 in the area of the Strait of Gibraltar (Fig. 1). At each sampling station, vertical profiles of temperature and salinity were obtained with a CTD-Rosette sampler, recording the water column properties from the surface to near the bottom. At each profile, 9 to 11 water samples were taken from the rosette to sample the Atlantic, Mediterranean and interface layers. From each water sample $4 \mathrm{ml}$ was preserved with glutaraldehyde (1\% final concentration) and stored in liquid nitrogen for flow cytometric analysis of autotrophic picoplankton and nanoplankton.

Laboratory methods. The estimation of the abundance of phytoplankton $<13 \mu \mathrm{m}$ was carried out through flow cytometry (FACScan, Becton-Dickinson). The equipment was configured as follows: Nanosetting: (mean fluorescence) FL1 $=450 \mathrm{mV}$, FL2 $=450 \mathrm{mV}$, FL3 $=300 \mathrm{mV}, \mathrm{SSC}=271, \mathrm{FSC}=\mathrm{E} 00$, threshold $=1$, analysed sample volume $=0.4 \mathrm{ml}$; Picosetting: FL1 $=$ $450 \mathrm{mV}$, FL2 = $555 \mathrm{mV}$, FL3 $=651 \mathrm{mV}, \mathrm{SSC}=402, \mathrm{FSC}$ $=\mathrm{E} 01$, threshold $=300$, analysed sample volume $=$ $0.24 \mathrm{ml}$. On the basis of red (>650 nm) and orange fluorescence (563 to $607 \mathrm{~nm}$ ) as well as side and forward light scatter (SSC and FSC, respectively) we identified 4 phytoplankton groups: Prochlorococcus, Synechococcus, eukaryotic picophytoplankton $(<2 \mu \mathrm{m}$ equivalent spherical diameter [ESD]) and eukaryotic nanophytoplankton (2 to $13 \mu \mathrm{m}$ ESD). Cell volume was

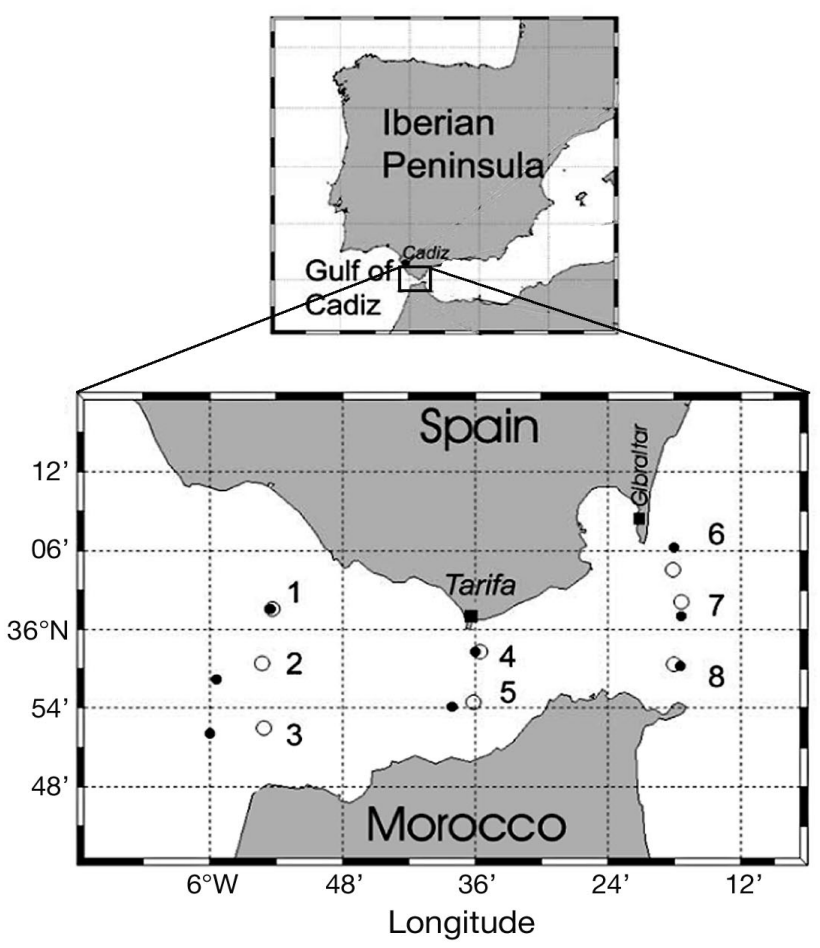

Fig. 1. Sampling site and sampling stations for the surveys in June ( ) and September (O). The 8 stations were sampled in W-E direction on 8 consecutive days

estimated from a calibration of the forward scatter signal ('nanosetting'), volume estimations through image analysis for cultured species (Synechococcus sp., Nannochloris atomus, Nannochloropsis gaditana, Isochrysis galbana, Phaeodactylum tricornutum, Tetraselmis chui) and different bead sizes (Coulter standard polystyrene latex beads 1.1, 2.85, 5.06 and $13.3 \mu \mathrm{m}$ ESD) (Fig. 2). We obtained a mean size distribution of Prochlorococcus sp. from flow cytometry analyses under 'nanosetting' equipment configuration, which was the same configuration used for the whole spectrum. However, their enumeration was carried out with the picosetting equipment configuration due to the dim fluorescence signal of Prochlorococcus sp. Thus, the size-abundance spectra of this group were obtained by multiplying this abundance by their mean size distribution.

Size-abundance spectra. Phytoplankton sizeabundance spectra (P-SAS) were obtained in 2 steps. First, cells were classified into $\log _{2}$ size classes. Second, a model I regression analysis was carried out between the log-transformed values of cell size and abundance. Nominal cell size, in volume units, was taken as the geometric mean of each size-class limit. The modal and size range of each identified group as well as the conversion factors used to calculate microbial biomass are given in Table 1 . 


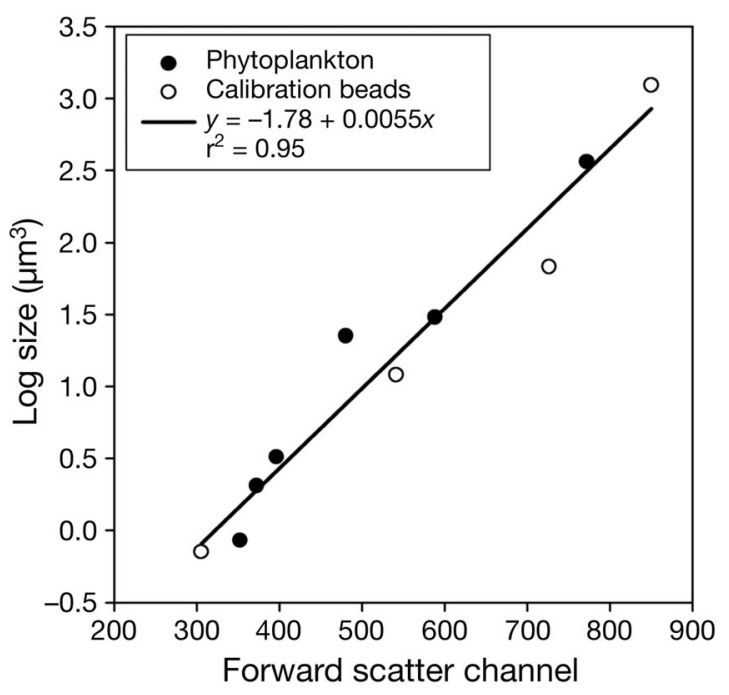

Fig. 2. Relationship between forward light scatter channel and particle size

\section{RESULTS}

\section{Physical environment}

The structure of a water column through the region of the Strait of Gibraltar showed the typical 3-layer pattern with Atlantic water (salinity < 37) at the surface and Mediterranean water (salinity $>37.5$ ) below, separated by the AMI (salinity 37.0 to 37.5) (Fig. 3). Exceptions were the northern Stns 1 and 6 with different temperature and salinity characteristics. The NW Stn 1 showed warm $\left(19^{\circ} \mathrm{C}\right)$ and fresh $(<36.25)$ water at the surface, but was not deep enough to include true Mediterranean water in the bottom layer, while the NE Stn 6 did not include Atlantic water at the surface because of the upwelling of Mediterranean water that pushes the cold $\left(15^{\circ} \mathrm{C}\right)$ and salty $(37.5)$ water of the interface to the surface. In fact, a striking observation was the depth variability of the AMI in the area. The AMI rose from almost $200 \mathrm{~m}$ off Cape Spartel (Stn 3) to a depth of $50 \mathrm{~m}$ at Tarifa (Stn 4), and reached the surface off Gibraltar (Stn 6).
All stations on the Atlantic side showed a cold $\left(<14^{\circ} \mathrm{C}\right)$ subsurface salinity minimum $(<36.25)$ getting deeper southward, which indicates the presence of North Atlantic Central Water (NACW). This signal vanished eastward from Stns 4 and 5, the Tarifa section.

A similar pattern was found during the September survey. Consequently, physical changes from June to September seem to be irrelevant in comparison to the strong spatial gradients in the region, and both surveys were considered representative of summer conditions and so spatial gradients are only shown for the June sampling.

\section{Plankton patterns}

All the microbial phytoplankton groups identified, except Prochlorococcus sp., were more abundant in the surface water of the northern Stns 1, 4 and 6 (Figs. 4 \& 5). Eukaryotic nanophytoplankton abundances were similar $\left(\sim 3000\right.$ cells $\left.\mathrm{ml}^{-1}\right)$ along the Spanish coast, from the warm $\left(17\right.$ to $\left.19^{\circ} \mathrm{C}\right)$, fresh $(<36.25)$ and nitrate-impoverished $(0.17 \pm 0.09 \mu \mathrm{M})$ Atlantic waters to the upwelled cold $\left(<16^{\circ} \mathrm{C}\right)$, salty (37.5) and nutrient-rich $(2.6 \pm$ $0.14 \mu \mathrm{M}$ nitrate and $0.24 \pm 0.009 \mu \mathrm{M}$ phosphate) waters of the Alboran Sea (Fig. 6). However, the small cells that constitute the eukaryotic picophytoplankton and Synechococcus sp. were remarkably more abundant

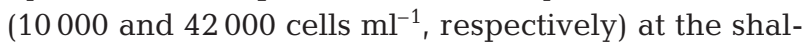
low NW Stn 1, with warm but phosphate-rich (0.34 \pm $0.14 \mu \mathrm{M}$ ) water (Fig. 6).

In contrast, Prochlorococcus sp. was restricted to the SW area (Stns 2 and 3) where the AMI location was deepest in the region $(200 \mathrm{~m})$. In fact, the highest abundance (110000 cells $\mathrm{ml}^{-1}$ ) was observed in the subsurface (40 to $60 \mathrm{~m}$ depth) Atlantic water (17 to $19^{\circ} \mathrm{C} ; 36.25$ to 36.50 salinity) off Cape Spartel, Morocco (Figs. 5 \& 6). This water mass was greatly nutrientdepleted, in both nitrate $(0.12 \pm 0.01 \mu \mathrm{M})$ and phosphate $(0.17 \pm 0.09 \mu \mathrm{M})$.

Consequently, Synechococcus sp. and Prochlorococcus sp. showed a contrasting N-S distribution at the western transect, but both decreased eastward along the strait.

Table 1. Conversion formulae used to estimate plankton biomass. $B_{m}$ : biomass (pg C), $B_{v}$ : biovolume ( $\left.\mu m^{3}\right)$, ESD: equivalent spherical diameter. The geometric mean of the modal size class and the size range covered by each identified group are also indicated

\begin{tabular}{|llccc|}
\hline Biological group & Group formula & $\begin{array}{c}\text { Modal size class } \\
(\mu \mathrm{m} \text { ESD })\end{array}$ & $\begin{array}{c}\text { Range } \\
(\mu \mathrm{m} \text { ESD })\end{array}$ & Source \\
\hline Prochlorococcus sp. & $\mathrm{B}_{\mathrm{m}}=0.053 \cdot$ cell & 0.7 & $0.4-1.5$ & Morel et al. (1993) \\
Synechococcus sp. & $\mathrm{B}_{\mathrm{m}}=0.25 \cdot$ cell & 1.39 & $0.4-1.97$ & Kana \& Glibert $(1987)$ \\
Eukaryotic nanophytoplankton & $\mathrm{B}_{\mathrm{m}}=0.433 \cdot\left(\mathrm{B}_{\mathrm{v}}\right)^{0.863}$ & 1.75 & $0.4-13$ & Verity et al. (1992) \\
\hline
\end{tabular}



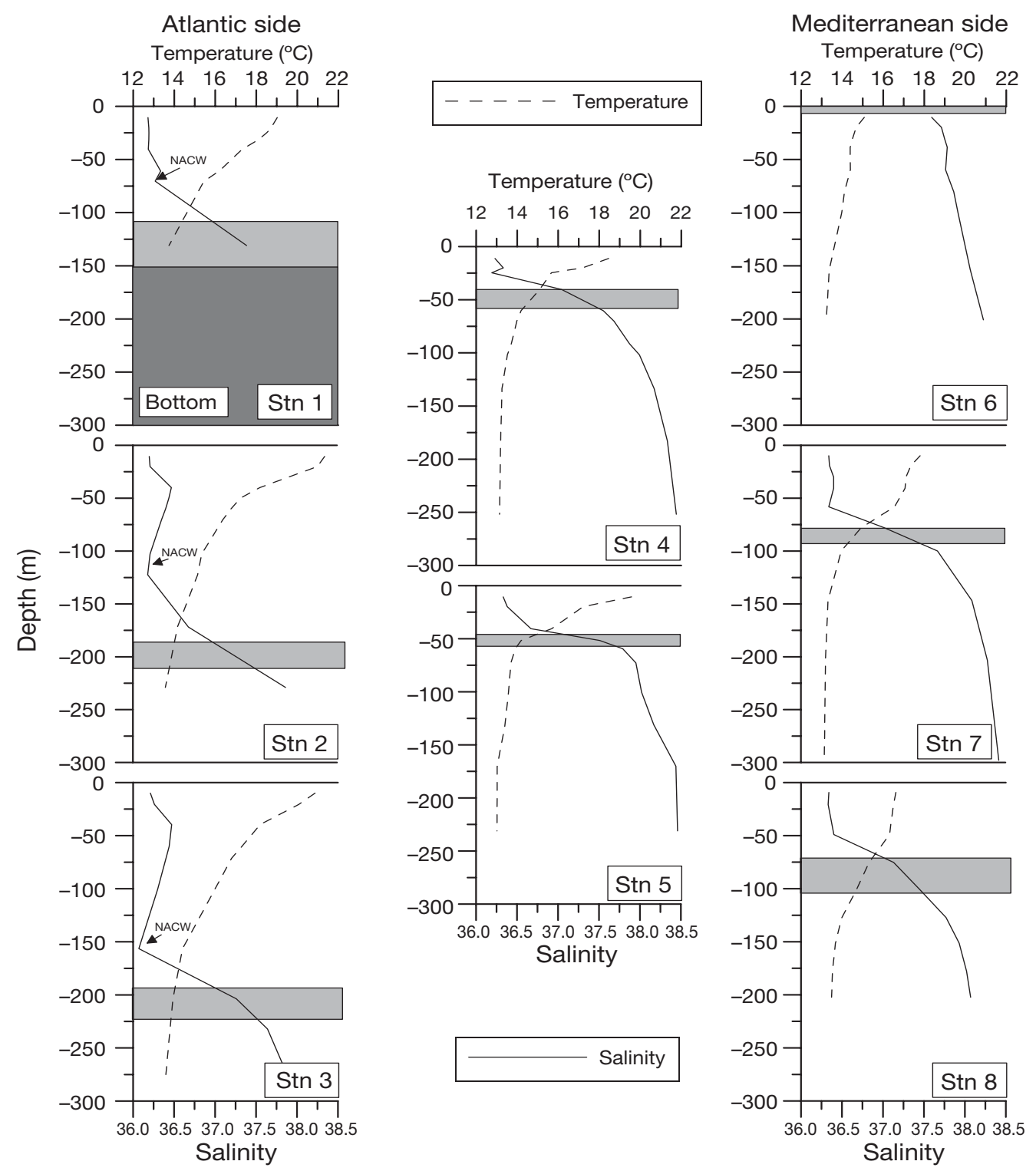

Fig. 3. Vertical temperature (dashed lines) and salinity (continuous lines) profiles for the survey in June. Grey rectangles indicate the width of the Atlantic-Mediterranean interface (AMI) defined between the isohaline of 37.0 and 37.5. When present, North Atlantic Central Water (NACW) signals are indicated. Dark grey rectangle indicates the seafloor (Bottom)

\section{Size structure of microbial plankton}

Fig. 7 shows the size structure of all identified microbial phytoplankton groups (P-SAS) at the subsurface biomass maximum for the 2 most distinct stations (Stns 3 and 6) of both surveys. The lineal fitting equations, corresponding to the sum of each size class, are shown in Table 2.

The slopes of the P-SAS in the Strait of Gibraltar area exhibit a high spatial variability (range: -0.22 to -0.91 ). The P-SAS corresponding to the NE area (Stn 6) were significantly flatter than those corresponding to the SW area (Stn 3$)$ in June and September ( $<0.05$; analysis of covariance [ANCOVA]). This is due to (1) the increasing abundance of nanophytoplankton, which lifts up the right side of the SAS, and (2) the decreasing abundance of prokaryotic picophytoplankton, particularly Prochlorococcus sp., which lowers the left side of the SAS (Fig. 7, Table 2). Taking into account all stations from the 2 surveys, the slope of the SAS becomes flatter (less negative) as the AMI emerges from the Atlantic SW area to the Mediterranean NE region of the strait (Fig. 8). In line with this trend, the depthaveraged microbial biomass in the water column $(100 \mathrm{~m})$ at $\operatorname{Stn} 6\left(51 \mathrm{mg} \mathrm{C} \mathrm{m}^{-3}\right)$ was about 3 times larger than at $\operatorname{Stn} 3\left(18 \mathrm{mg} \mathrm{C} \mathrm{m}^{-3}\right)$. 

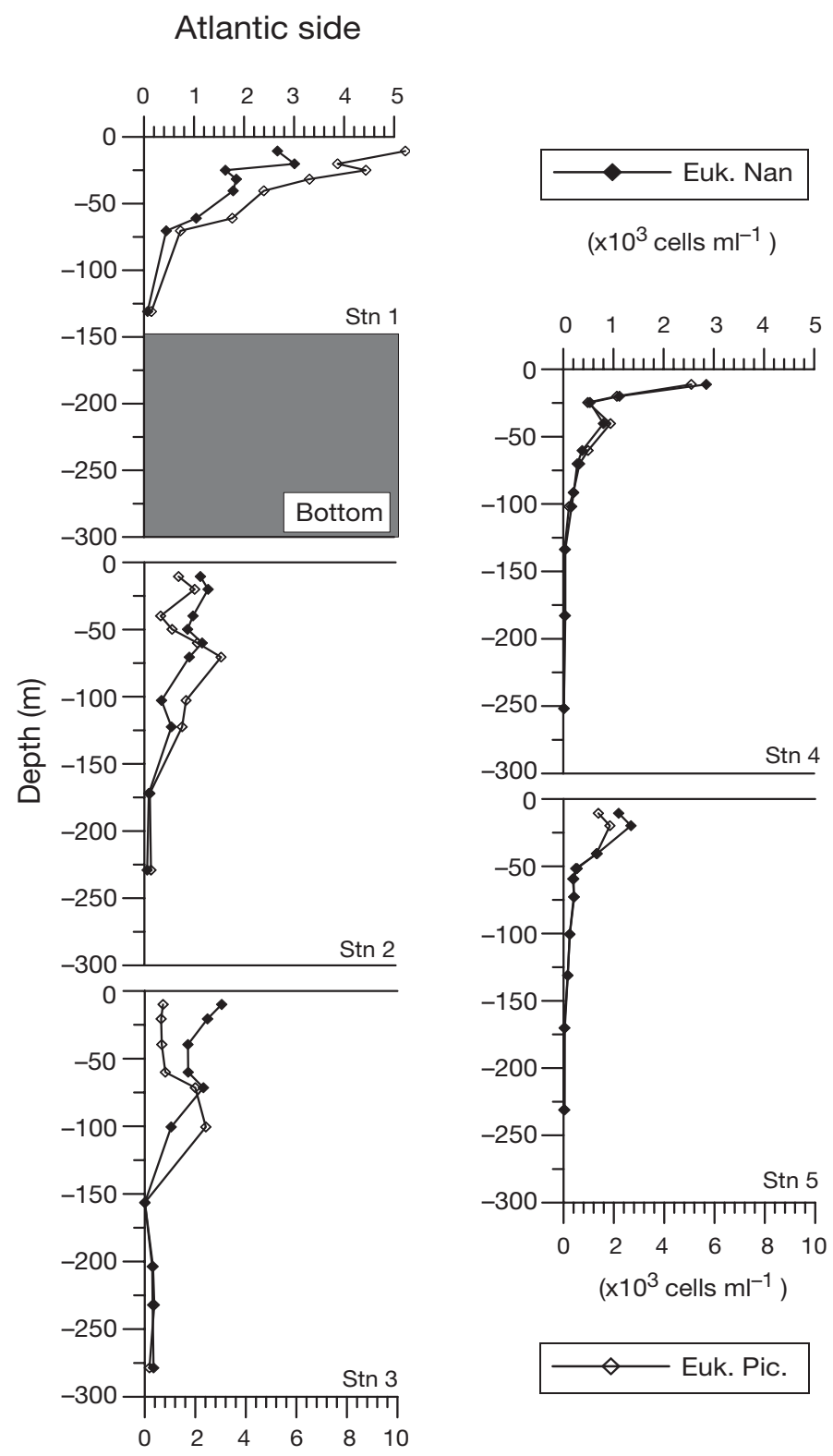

Mediterranean side

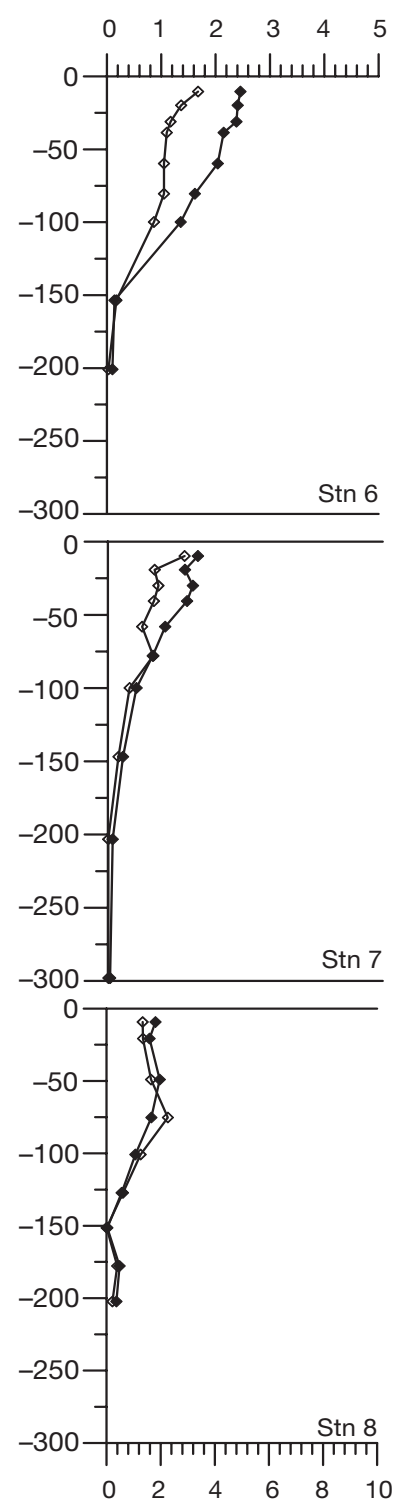

Fig. 4. Vertical profile of eukaryotic picophytoplankton (Euk. Pic.) and nanophytoplankton (Euk. Nan.) for the survey in June

\section{DISCUSSION}

\section{Distribution patterns of nano- and picophyto- plankton}

The observed spatial distribution of the phytoplankton groups identified reveals strong changes in the microbial community composition in terms of abundance, size structure and biomass, especially along a SW-NE axis through the strait.

High values of phytoplankton biomass have usually been reported, closely associated with nano- and microplankton (Rodríguez et al. 1998). In the Strait of
Gibraltar, we recorded high abundance of nanophytoplankton at the northern stations of the transects, both westward and eastward of the Tarifa section. On the Atlantic side, the productive, fresh (salinity < 36.25) and warm $\left(>17^{\circ} \mathrm{C}\right)$ shelf water of the Gulf of Cadiz should supply enough nitrate and phosphate to support the high concentration of nanophytoplankton observed (3000 cells ml $\mathrm{ml}^{-1}$ ), although probably the rapid incorporation of nitrate by large phytoplankton, mainly diatoms (Echevarría et al. 2002), was apparently responsible for the low concentration of nitrate measured $(0.1 \mu \mathrm{M})$. On the Mediterranean side, the high phytoplankton biomass and abundance of nanophyto- 

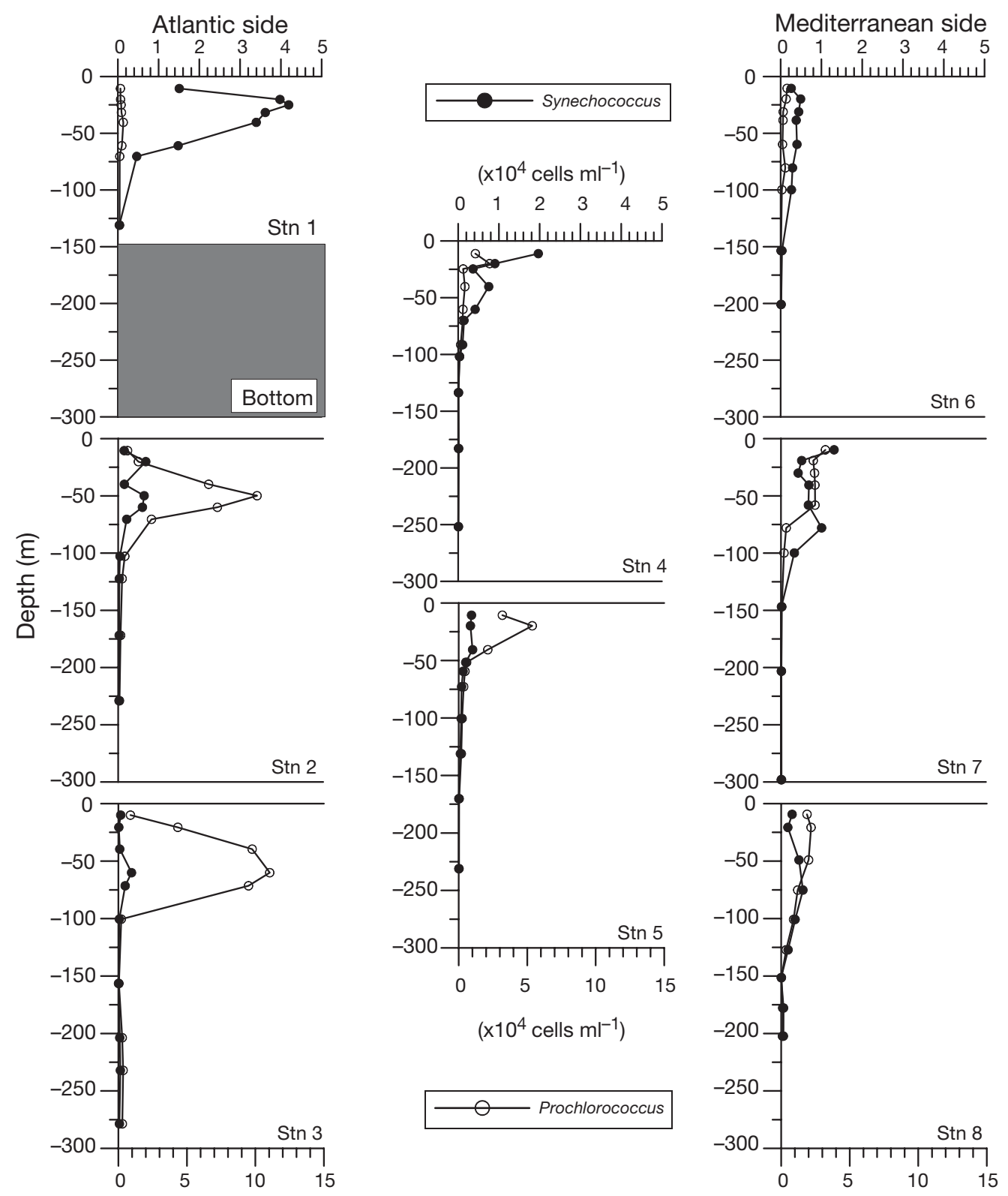

Fig. 5. Vertical profile of prokaryotic picophytoplankton (Synechococcus and Prochlorococcus) for the survey in June

plankton is related to several complementary fertilization processes. The rising AMI from the SW to the NE regions causes mixing processes that affect temperature, salinity and nutrient concentration, leading to a fertilization of the water above the seasonal thermocline. In fact, Echevarría et al. (2002) related NACW signals in the upper layer of the eastern part of the strait to the semidiurnal tidal cycle, suggesting a pulsating input of nutrient-rich NACW in the Atlantic jet. These pulsating upwelling events have previously been suggested as an explanation for the SW-NE increase of integrated chl a concentration and diatom abundance (Echevarría et al. 2002).
On the other hand, increasing nutrient and phytoplankton concentration at the NE part of the strait is not necessarily or exclusively the consequence of hydraulic processes inside the strait, but also the result of upwelling processes that occur in the NW Alboran Sea and occasionally extend to the Strait of Gibraltar area (Reul et al. 2005).

Picophytoplankton showed a distribution opposite to that of Synechococcus sp. in the north and Prochlorococcus sp. in the south of the Atlantic transect. At the same time, we observed a W-E decrease in both prokaryotes from the Atlantic to the Mediterranean side. The decrease in both prokaryotes towards the 

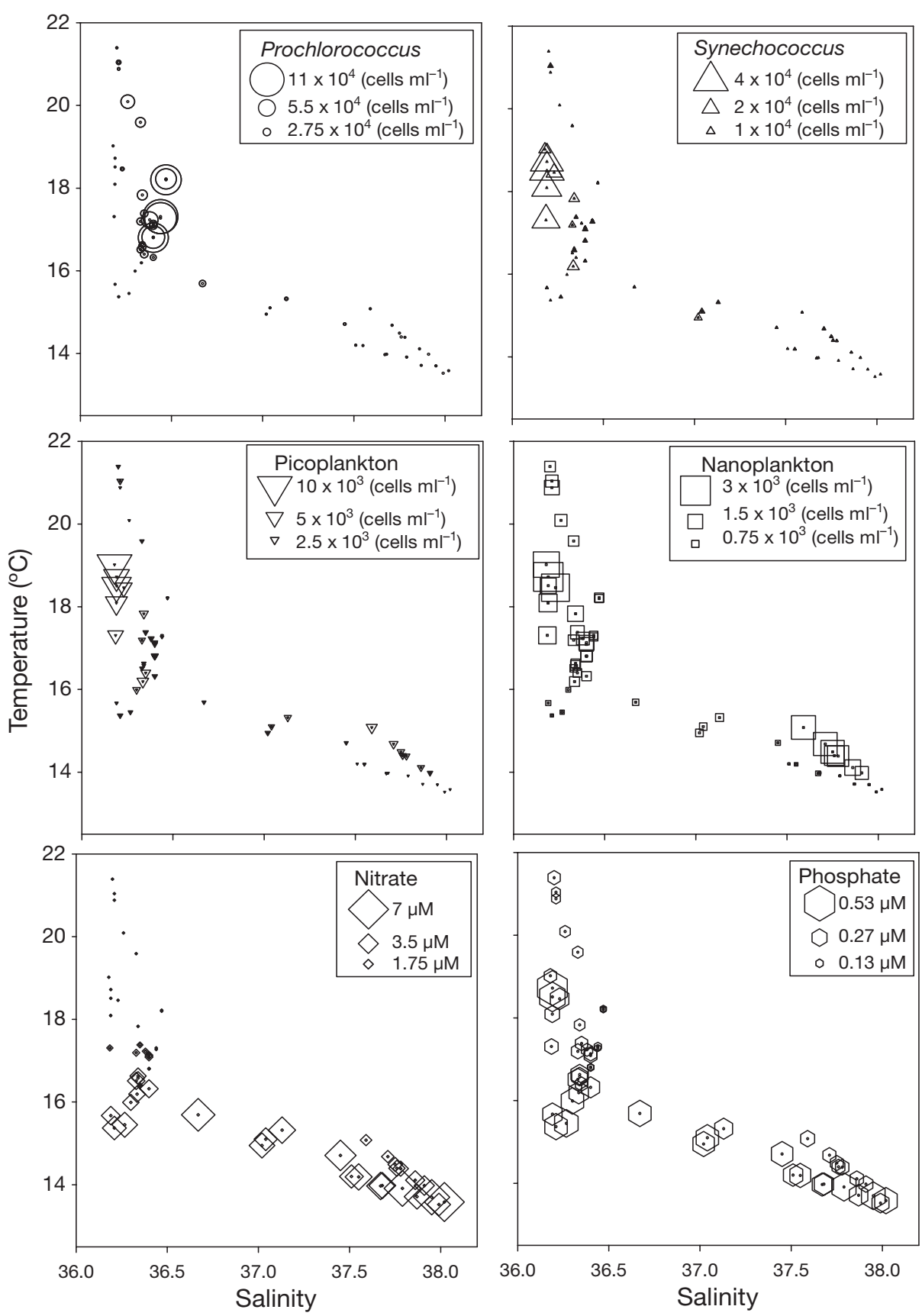

Fig. 6. Phytoplankton abundance and nutrient concentration in the upper $100 \mathrm{~m}$ on temperature-salinity plots for the June survey. Symbol sizes of each plot refer to the maximum abundance or nutrient concentration measured in the upper $100 \mathrm{~m}$

Mediterranean might be due to temperature limitation, although only at Stn 6 was the whole water column colder than the limiting temperature of $15^{\circ} \mathrm{C}$ proposed by Moore et al. (1995). They described the limitation for the Prochlorococcus sp. SS120 and the Synechococcus sp. WH8103 clones from the Sargasso Sea at temperatures $<15^{\circ} \mathrm{C}$, while the Mediterranean Prochlorococcus sp. clone MED4 persists at lower temperatures $\left(>12.5^{\circ} \mathrm{C}\right)$. Similary, Olson et al. (1990) suggested a limitation for Prochlorococcus sp. at low temperatures to explain (1) the restriction of Prochlorococcus sp. to lower latitudes than Synechococcus sp. and (2) the later spring bloom of Prochlorococcus sp. than Synechococcus sp. Another factor might be dilution processes due to the mixing of Atlantic and Mediterranean water along the strait, which could imply selection processes among the physiological and genetically different Prochlorococcus sp. strains described for the Atlantic and Mediterranean (Moore et al. 1995, 2002). 


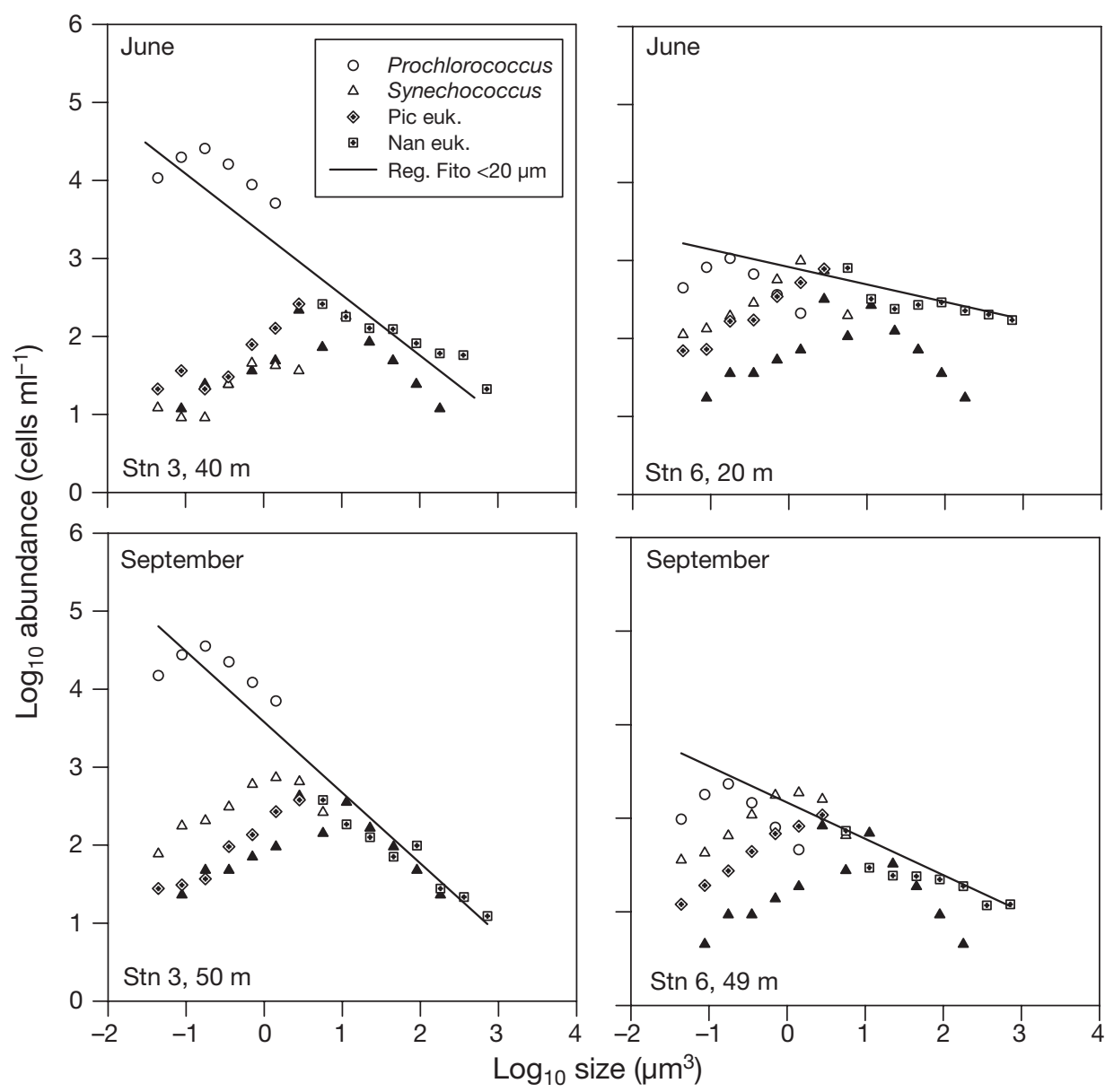

Fig. 7. Size distribution of the identified groups at the subsurface biomass maximum at the SW station (Stn 3) and NE station (Stn 6) in June and September. Continuous line represents the linear adjustment (Reg. Fito) fitted to the phytoplankton size-abundance spectrum (P-SAS) considering the whole abundance value of each size class

With respect to the N-S segregation of Synechococcus sp. and Prochlorococcus sp. on the Atlantic side of the strait, both prokaryotes were found at similar temperatures $\left(17\right.$ to $\left.19^{\circ} \mathrm{C}\right)$ but with distinct salinity values (Fig. 6), which indicates a different origin of the respective water masses. However, it is not the salinity but the different trophic states which might be the key factor for this opposite distribution. At the Atlantic transect all samples with temperatures $>17^{\circ} \mathrm{C}$ were nitrate-poor, but warm samples with salinity $<36.25$ (only found at Stn 1) were phosphate-rich, indicating the influence of warm, nutrient-rich shelf water of the Gulf of Cadiz at the NW station, where the highest Synechococcus sp. abundance was recorded. In contrast, Prochlorococcus sp. proliferate in the SW part of the strait (Stn 3, temperature $>17^{\circ} \mathrm{C}$, salinity $>36.25$ ), in nutrient- (nitrate and phosphate) depleted water, i.e. under 'real' oligotrophic conditions as described for the

Table 2. Parameters of the regression models and the ANCOVA between the phytoplankton size-abundance spectrum (P-SAS) at the SW station (Stn 3) and NE station (Stn 6) in June and September. ${ }^{*} p<0.01$, ns $=$ not significant

\begin{tabular}{|lccccccccccc}
\hline Survey & Stn & Depth $(\mathrm{m})$ & Intercept (a) & SD & Slope (b) & SD & $\mathrm{R}^{2}$ & $\begin{array}{c}\mathrm{p} \\
\mathrm{ANCOVA} \\
\mathrm{b}\end{array}$ \\
\hline Jun & 3 & 40 & 3.44 & 0.11 & -0.78 & 0.072 & 0.898 & $*$ & ns & $*$ \\
& 6 & 20 & 2.92 & 0.067 & -0.22 & 0.045 & 0.66 & $*^{*}$ \\
Sep & 3 & 50 & 3.58 & 0.096 & -0.91 & 0.064 & 0.940 & $*$ & ns & $*$ \\
& 6 & 49 & 3.17 & 0.082 & -0.38 & 0.055 & 0.792 & $*$ & \\
\hline
\end{tabular}




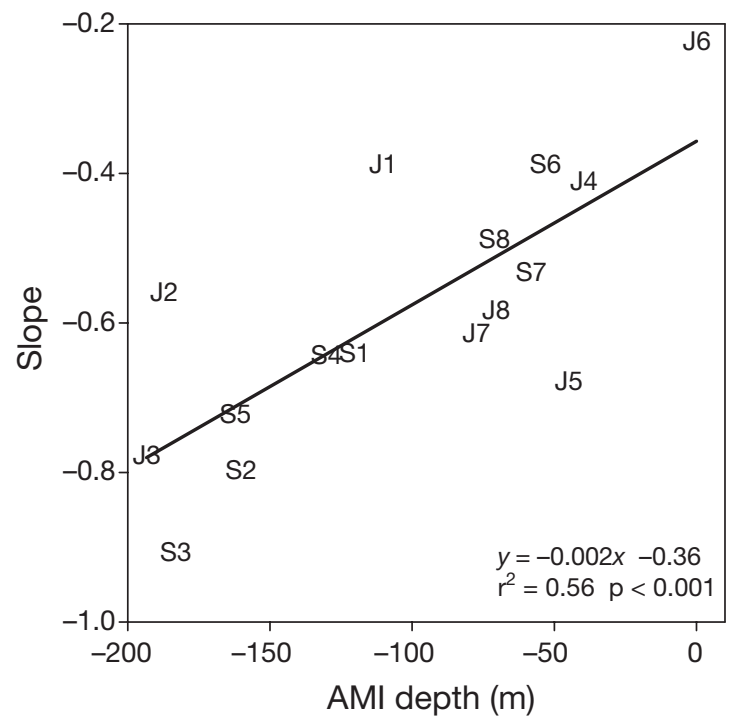

Fig. 8. Regression between the slope of the phytoplankton size-abundance spectrum (P-SAS) (J1 to J8 for June and S1 to $\mathrm{S} 8$ for September) at the subsurface biomass maximum and the depth of the Atlantic-Mediterranean interface (AMI) defined as the isohaline 37.0

North Atlantic (Zubkov et al. 1998) and the adjacent Alboran Sea (Reul et al. 2005).

Apparently, the smaller cell size and higher absorption efficiency in the blue light (Morel et al. 1993) allows Prochlorococcus sp. to prevail in oligotrophic stratified water using $\mathrm{NH}_{4}{ }^{+}$and $\mathrm{NO}_{2}{ }^{-}$as a nitrogen source (Moore et al. 2002) and perhaps taking advantage of the $\mathrm{NO}_{2}{ }^{-}$maximum associated with a deeper nitracline, inaccessible to Synechococcus sp. Finally, the uptake of organic nitrogen compounds might be the key factor in explaining the dominance of Prochlorococcus sp. in oligotrophic waters.

\section{Size structure}

The first empirical studies carried out in oceanic, steady-state, pelagic systems revealed a 'universal' slope of SAS of -1 (Sheldon et al. 1972). In a broad view, Quiñones et al. (2003) described the difficulty of establishing a unique reference point for the slope under steady-state conditions because of the variable ratio among unicells, heteroterms and homoterms in pelagic ecosystems, and showed the importance of the regularity and linearity of size spectra in close steadystate systems rather than the numeric value of the slope. However, in the present study, carried out from steady-state to non-steady-state conditions, it is assumed that the primary benefit of the SAS approach is for comparative studies of unicellular communities within the same size range. The forcing factors in per- turbed pelagic ecosystems are different, and the SAS might not always present a linear relationship or exhibit slopes significantly different from -1 .

In fact, the slope of the observed P-SAS at the Strait of Gibraltar ranges from -0.91 to -0.22 and smoothes as AMI moves upwards, indicating a gradient from oligotrophic steady-state conditions from the SW station to perturbed conditions at the NE station, where nanophytoplankton benefits from nutrient input and is maintained in suspension by increasing turbulence and positive vertical motion (Rodríguez et al. 2001). Also, in the adjacent Alboran Sea, Rodríguez et al. (1998) described a steeper slope (-0.93) under anticyclonic circulation with a deeper AMI but a flatter slope $(-0.78)$ under cyclonic circulation with a shallower AMI, due to increasing abundance of nanophytoplankton and microplankton.

A recognised paradigm is that increasing nutrient availability due to mixing processes fuels the growth of nano- and microplankton and leads to an increase in large cells at the right part of the P-SAS, which smoothes the slope. Moreover, according to Stokes' law and empirical studies, settling velocities of cells are related to cell size, and retention of cells in the water column is required to avoid the loss of big cells from the water column. Rodríguez et al. (2001) demonstrated the direct effect of vertical velocities on the slope of SAS; positive vertical velocities directly counteracted the settling velocities leading to SAS with a slope that is less negative than -1 , irrespective of nutrient availability. On a macroscale, Cavender-Bares et al. (2001) did not find an overall relationship between the slopes (range: -1.4 to -1.0 ) of microbial (cells $<5 \mu \mathrm{m})$ SAS and nutrient concentration across the North Atlantic, but described a positive correlation between the slope and nutrient concentration for the Sargasso Sea and the northern edge of the Gulf Stream.

In the present study, the changes of the P-SAS slope found in the Strait of Gibraltar are not only due to the variability of nanophytoplankton abundance but are also influenced by the remarkable variability in the abundance of prokaryotic picophytoplankton, especially Prochlorococcus sp., which is not always considered in SAS analysis. It is known that the abundance of Prochlorococcus sp. is much lower $\left(3 \times 10^{4}\right.$ to $6 \times$ $10^{4} \mathrm{cells} \mathrm{ml}^{-1}$ ) in the Alboran and Mediterranean Seas (Vaulot \& Partensky 1990, Reul et al. 2005) than in the North Atlantic $\left(10 \times 10^{4}\right.$ to $28 \times 10^{4}$ cells ml $^{-1}$, Zubkov et al. 1998). The abundance of Prochlorococcus sp. decreases through the strait without being substituted by any phototrophic organism of similar size. Consequently, the P-SAS becomes flatter towards the NE because of the combined effect of increasing nanophytoplankton abundance at the right extreme of the 
P-SAS and decreasing abundance of prokaryotic picophytoplankton at the extreme left of the P-SAS. This finding concurs with the theoretical approach of Irwin et al. (2006), who explain the decrease in Prochlorococcus sp. and smoothing of the SAS slope with increased nutrient supply, growth rate and dilution processes. At the same time, the higher absorption efficiency of a smaller cell size in blue light (Morel et al. 1993) contributes to a steeper slope of the P-SAS in deep waters of the SW station, owing to the dominance of picophytoplankton cells.

\section{CONCLUSIONS}

The Atlantic-Mediterranean water exchange and related mixing processes through the Strait of Gibraltar affect the functional composition and size structure of microbial phytoplankton. Using the depth of the AMI as an indicator for the perturbation of the water column structure, it is possible to assess the shift of phytoplankton size spectra towards bigger cells as perturbation increases from SW to NE. In contrast to other regions, the smoothing of the slope is due not only to the increase in nanophytoplankton, but also to the decrease in picophytoplankton (mainly Prochlorococcus sp.) abundances. At the western side of the strait, Synechococcus sp. appear to benefit from increasing nitrate concentration at the northern coastal station, while Prochlorococcus sp. dominate under oligotrophic open ocean conditions in the south, probably using ammonium and organic compounds as nitrogen sources.

Acknowledgements. This work was supported by the European Commission through the CANIGO Project (MAS3-P1950443). A.R. was also supported by the CANIGO EU Project. We are indebted to the captain and crew of the RV 'Cornide de Saveedra' from the IEO and the captain and crew of the RV 'Thalassa' from IEO/IFREMER.

\section{LITERATURE CITED}

Cavender-Bares KK, Rinaldo A, Chisholm SW (2001) Microbial size spectra from natural and nutrient enriched ecosystems. Limnol Oceanogr 46:778-789

Echevarría F, Lafuente JG, Bruno M, Gorsky G and others (2002) Physical-biological coupling in the Strait of Gibraltar. Deep-Sea Res II 49:4115-4130

García-Lafuente J, Vargas JM, Plaza F, Sarhan T, Candela J,

Editorial responsibility: Josep Gasol,

Barcelona, Spain
Bascheck B (2000) Tide at the eastern section of the Strait of Gibraltar. J Geophys Res 105:14197-14213

Irwin AJ, Finkel ZV, Schofield OME, Falkowski PG (2006) Scaling-up from nutrient physiology to the size-structure of phytoplankton communities. J Plankton Res 28:459-471

Kana TM, Glibert PM (1987) Effect of irradiance of up to 2000

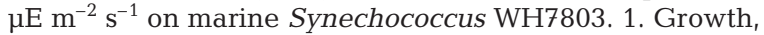
pigmentation and cell composition. Deep-Sea Res 34: 479-495

Malone TC (1980) Algal size. In: Morris I (ed) The physiological ecology of phytoplankton. Blackwell Scientific Publications, Oxford, p 433-463

> Moore LR, Goerick R, Chisholm SW (1995) Comparative physiology of Synechococcus and Prochlorococcus: influence of light and temperature on growth, pigments, fluorescence and absorptive properties. Mar Ecol Prog Ser 116:259-275

Moore LR, Post AF, Rocap G, Chisholm SW (2002) Utilization of different nitrogen sources by the marine cyanobacteria Prochlorococcus and Synechococcus. Limnol Oceanogr 47:989-996

Morel A, Ahn YH, Partensky F, Vaulot D, Claustre H (1993) Prochlorococcus and Synechococcus: a comparative study of their optical properties in relation to size and pigmentation. J Mar Res 51:617-649

Olson RJ, Chisholm SW, Zettler ER, Altabert MA, Dusenberry JA (1990) Spatial and temporal distributions of prochlorophyte picoplankton in the North Atlantic Ocean. DeepSea Res 37:1033-1051

Platt T, Denman K (1977) Organization in the pelagic ecosystem. Helgol Wiss Meeresunters 30:575-581

- Quiñones RA, Platt T, Rodríguez J (2003) Patterns of biomasssize spectra from oligotrophic waters of the Northwest Atlantic. Prog Oceanogr 57:405-427

Reul A, Rodríguez V, Jiménez-Gómez F, Blanco JM and others (2005) Variability in the spatio-temporal distribution and size-structure of phytoplankton across an upwelling area in the NW-Alboran Sea, (W-Mediterranean). Cont Shelf Res 25:589-608

Rodríguez J, Blanco JM, Jiménez-Gómez F, Echevarría F and others (1998) Patterns in the size structure of the phytoplankton community in the deep fluorescence maximum of the Alboran Sea (southwestern Mediterranean). DeepSea Res 45:1577-1593

- Rodríguez J, Tintoré J, Allen JT, Blanco JM and others (2001) Mesoscale vertical motion and the size structure of phytoplankton in the ocean. Nature 410:360-363

Sheldon RW, Prakash A, Sutcliffe WH (1972) The size distribution of particles in the ocean. Limnol Oceanogr 17:327-340

Vaulot D, Partensky F (1990) Winter presence of prochlorophytes in surface waters of the Northwestern Mediterranean Sea. Limnol Oceanogr 35:1156-1167

Verity P, Robertson CY, Tronzo CR, Andrews MG, Nelson JR, Sieracki ME (1992) Relationship between cell volume and carbon and nitrogen content of marine photosynthetic nanoplankton. Limnol Oceanogr 37:1434-1446

- Zubkov MV, Sleigh MA, Tarran GA, Burkill PH, Leakey RGJ (1998) Picoplanktonic community structure on Atlantic transect from $50^{\circ} \mathrm{N}$ to $50^{\circ} \mathrm{S}$. Deep-Sea Res 45:1339-1355

Submitted: February 21, 2008; Accepted: May 29, 2008

Proofs received from author(s): September 5, 2008 